\title{
Environment analysis of the Training in Employment Courses (TEC) in ICT sector in Morocco.
}

\author{
AnajarAbdelhak $^{\mathrm{a}}$, TalbiMohammed ${ }^{\mathrm{a}}$, TraghaAbderrahim ${ }^{\mathrm{b}}$ \\ ${ }^{a}$ Observatory of Research in Teaching and University Pedagogy (ORDIPU), School of Science Ben M'sik, \\ Hassan II University, Mohammedia-Casablanca,Morocco. \\ ${ }^{b}$ Research Laboratory: Information Processing and Modelisation, School of Science Ben M'sik, Hassan II \\ University, Mohammedia-Casablanca,Morocco.
}

\begin{abstract}
Training in Employment Courses (FCE) is the anchor of Vocational Training in the workplace, enhancing the dynamics of investment in human resources and business development partnership. The workplace becomes a privileged space for skills development through the promotion of alternate training and learning, internships' obligation and the introduction of professional juries for residential training.

In order to assess the current situation for both customers of the TEC in ICTs in Morocco for its service, and enjoy their experience in the field and examine the possibilities of development of this sector, we have conducted a survey of a sample of organizations prior to processing and analysis of data collected in the field.
\end{abstract}

Keywords: Education, ICT, On-the-job, training, Vocational.

\section{Introduction}

Vocational Training: Vocational training can be defined as a system which, from academic or professional prerequisites, prepares applicants to exercise and adapt to a job. It is a lever for improving employability and an instrument to upgrade the skills of companies. Therefore, it can not be conceived and executed outside the socio-economic and cultural objectives of the public policies. Thus defined, the field of vocational training seems quite extensive and requires for a better understanding of the issues, further analysis reflecting its linkages with economic, employment and education policies.

\section{The Training in Employment Courses (TEC):}

Training in Employment Courses: it is a practical training which is given in the workplace during the execution of transactions or normal production tasks. (Quebec Office of the French Language).

The use of the term on the job training is more familiar in this direction. Some authors prefer to designate a training which, by nature, is neither planned nor structured, and which is mainly the observation of an experienced worker performing his work.

Training in Employment Courses (FCE) is the anchor of Vocational Training in the workplace, enhancing the dynamics of investment in human resources and business development partnership. The workplace becomes a privileged space for skills development through the promotion of alternate training and learning, internships' obligation and the introduction of professional juries for residential training.

In order to assess the current situation for both customers of the TEC in ICTs in Morocco for its service, and enjoy their experience in the field and examine the possibilities of development of this sector, we have conducted a survey of a sample of organizations prior to processing and analysis of data collected in the field.

\section{On-Field Research:}

During our research, we found it very rewarding to make contact on the field, with the operators concerned in order not only to assess their views regarding the TEC's activity in ICT in Morocco but also to acquire personal experience by making us aware of the difficulties of the field. Thus the questionnaire survey is complemented by assessments of key actors and organizations involved in TEC in ICT in Morocco, testimonials obtained through the development of an interview guide.

The different actors sought stressed the confidentiality of information provided in the questionnaires and interviews. The survey results are drawn from the analysis of data collected after processing the questionnaires and observations made during the interviews.

\section{Deployment phase : Some precisions :}

1. Questionnaire:

The developed questionnaire is addressed to both recipients and clients of TEC in ICT, with the aim to collect information on TEC in ICT in Morocco through the experiences of the different operators. We conducted 
our investigation by submitting our questionnaire to 30 companies and institutions whose business calls TEC in ICT in Morocco (ITCompetences, Omnidata, GSI Maroc, ANRT, IAM, Banquepopulaire, Barid Al Maghrib, OFPPT, ...).

The sample of people asked to answer the questionnaire is representative and concerns the actors capable to meet all qualitative and quantitative aspects presented in the Questionnaire.

The questionnaire has 76 questions divided into four themes. After general questions about the organization that responded to the questionnaire (main activity of the organization, organizational structure, turnover, level of education of employees).

The first theme focuses on seven semi-open questions that are mainly about the place and role of ICT in the organization in question, the usefulness of ICT, availability of ICT skills ...

The second theme has 7 questions most of which are closed-type (6 of 7 questions). It tries to highlight the ICT training policy adopted by the organization.

The third theme of the questionnaire contains 8 closed questions and focuses on ICT training within the company / organization.

The fourth theme challenges the quality and environment of TEC in ICT and covers 43 questions in which 25 are closed-type and 18 semi-open. It is interested in the influence of certain quality criteria for training, in the TEC in ICT environment in Morocco and its impact on the availability of human resources for TEC in ICT, also in training themes provided by TEC providers in ICT and in the possible evolution of this sector of ICT training.

For evaluation of the Questionnaire and feedback on the perception of the Questionnaire, 4 closed-type questions are presented at the end of the questionnaire.

\section{The interview:}

The interview is intended to complement the data collected by the questionnaire. This is an semidirective interview in which the interviewee gives his opinion on a theme spontaneously. The questions are open and themes of revival are provided in the interview guide that has been developed for this purpose. Morocco.

We conducted interviews with 15 actors whose professional activity is concerned by the TEC in ICT in

The sample of people selected for this interview survey is representative since it concerns people who can answer the interview questions. So these are companies operating in IT, Networks, Telecom and still have to think about training their staff in ICT.

The interview consists of three themes or parts.

The first theme focuses on the TEC in ICT in the host organism and Morocco. It is an introductory phase to allow introducing the problematic, to collect the prerequisites for centering the speech on the main subject that examines the challenges and perspectives of TEC in ICT in Morocco.

The second theme concerns the analysis of the environment of TEC in ICT and seeks to determine the objective conditions for integrating ICT in the business, the role of the TEC in ICT to achieve its objectives and possible reasons that could explain its adoption or rejection.

The third theme strives to question the development strategy of the TEC sector in ICT in Morocco to better advance the activity of TEC in ICT in Morocco. It speaks to potential developments and steps to integrate a success strategy for TEC in ICT in Morocco.

Among the sampling criteria that justify the choice of interviewees in the sample of the interview are:

The degree of penetration and use of ICT in the activities of the organization in question: The choice of this criterion is justified by the link that can be established between,on the one hand, the nature of the organization's products and dependence of its activities towards ICT and, on the other hand, on its integration into training policy in ICT for the benefit of its employees.

Among the sampling criteria that justify the choice of respondents in the sample of the interview are:

Number of Employees : This criterion will not deviate small or medium size businesses to better understand the needs of this important segment, since small businesses with reduced staff working in the field of ICT generally require sharp profile in terms of TEC themes in ICT.

The scope of the survey: Rabat axis

\section{Data Processing And Results:}

For clarity, we chose to present the results of the investigation by theme to highlight trends and directions defined by both clients and recipients of TEC in ICT in Morocco. 


\section{Questionnaire:}

For the Questionnaire, we present in the following 13 questions from the 76 questions that make up the Questionnaire. Indeed, it would be comprehensive to identify all the issues with the synthesis of the Questionnaire's responses. That is why we tried to choose questions that are most relevant and the most representative and are based on the 4 topics covered by the questionnaire:

Table 01 . Question N 01

\begin{tabular}{|l|l|}
\hline \multirow{2}{*}{ Question } & $\begin{array}{l}\text { Degree of difficulty of the conditions of the activity of TEC in ICT in Morocco: } \\
\text { A-Great difficulty } \\
\text { B-Medium difficulty } \\
\text { C-Minimal difficulty } \\
\text { Please give reasons for your choice of degree of difficulty: }\end{array}$ \\
\hline \multirow{2}{*}{ RESULTS } & $\begin{array}{l}1.37 .50 \% \text { of organizations believe that the conditions of the activity of ICT in Morocco know great difficulty, } \\
\text { while } 62.50 \% \text { think it is medium difficulty. } \\
2.50 \% \text { of clients of TEC in ICT opt for great difficulty and } 50 \% \text { think it is of medium difficulty } \\
3.25 \% \text { of organizations also that consider themselves as clients as well as training recipients believe it's of great } \\
\text { difficulty, while } 75 \% \text { say it is a medium difficulty }\end{array}$ \\
\hline LESSONS & $\begin{array}{l}\text { None of the organizations minimizes the difficulty of the situation of TEC activity in ICT in Morocco. Despite the } \\
\text { problems that can occur in the area, the answer that comes up most concerns the average difficulty. This denotes a } \\
\text { reasonably tough environment and clients are the ones who feel more difficulty on the training. The reasons } \\
\text { mentionned concern the scarcity of professional providers of TEC in ICT, low budgets for training, lack of } \\
\text { information providing visibility about ICT training offers, lack of Customization of TEC in ICT according to the } \\
\text { client ... }\end{array}$ \\
\hline
\end{tabular}

Table02 . Question N 02

\begin{tabular}{|l|l|}
\hline Question & $\begin{array}{l}\text { ICT is for you: } \\
\text { A- an asset (business structuring element) } \\
\text { B- a resource (raw material used by the company) } \\
\text { Explain the reason for your choice: }\end{array}$ \\
\hline RESULTS & $\begin{array}{l}\square \text { Both answers, «ICT is an asset (business structuring element)) » and « ICT as a resource (raw material } \\
\text { used by the company) », share each the percentage of 50\%. }\end{array}$ \\
\hline $\begin{array}{l}\text { LESSONS } \\
\text { CND }\end{array}$ & $\begin{array}{l}\text { The results show the increasingly dominant role played by ICT in any organization. They represent both a } \\
\text { structural element for the company and a raw material that the company uses for production needs. }\end{array}$ \\
\hline
\end{tabular}

Table03 . Question N 03

\begin{tabular}{|c|c|}
\hline Question & $\begin{array}{l}\text { For Your Business, ICT allows or represents : } \\
\text { A- time saved } \\
\text { B- reduced costs } \\
\text { C- a better organization of work and daily management } \\
\text { D- a customer loyalty and win of new markets } \\
\text { E- simplification of administrative procedures } \\
\text { F- an absolute necessity }\end{array}$ \\
\hline RESULTS & $\begin{array}{l}\text { Percentages of responses for the benefits are as follows: } \\
\square \quad 21.05 \% \text { for « reduced costs » and « an absolute necessity » } \\
\square \quad 18.42 \% \text { to « time saved » and « a better organization of work and daily management » } \\
\square 10.53 \% \text { for « a customer loyalty and win of new markets » and « simplification of administrative procedures » }\end{array}$ \\
\hline $\begin{array}{l}\text { LESSONS } \\
\text { AND } \\
\text { COMMENTS }\end{array}$ & $\begin{array}{l}\text { The perception of ICT as an enabler of administrative procedures is still low, which proves that the state has yet to } \\
\text { deploy efforts to consolidate and disseminate its e-Morocco policy and e-Government. }\end{array}$ \\
\hline
\end{tabular}

Table04 . Question N 04

\begin{tabular}{|c|c|}
\hline Question & $\begin{array}{l}\text { Is there a training in employment courses policy applied at your workplace? } \\
\text { A YES. For what purpose? } \\
\text { A-1-Qualification for a specific task } \\
\text { A-2-Employees profile improvement to meet the challenges due to market changes } \\
\text { A-3-Employees profile improvement to cope with labor conditions changes } \\
\text { B NO }\end{array}$ \\
\hline RESULTS & $\begin{array}{l}\quad 80 \% \text { of organizations believe they have indeed a TEC policy, against } 20 \% \text { who think the opposite. } \\
\text { The objectives mentioned by these } 80 \% \text { are as follows: } \\
\square \quad 42.86 \% \text { of the responses for " Employees profile improvement to meet the challenges due to market changes » } \\
\square \quad 21.43 \% \text { are for « Employees profile improvement to cope with labor conditions changes » } \\
\square \quad 35.71 \% \text { are for « Qualification for a specific task » }\end{array}$ \\
\hline $\begin{array}{l}\text { LESSONS } \\
\text { AND } \\
\text { COMMENTS }\end{array}$ & $\begin{array}{l}\text { We notice an increasing awareness of companies vis-à-vis the sudden and frequent changes of markets and the } \\
\text { role TEC holds in the right accompaniment of these changes. More specifically, the use of ICT has invested all } \\
\text { forms of management, operation and control. }\end{array}$ \\
\hline
\end{tabular}




\section{Table05. Question N 05}

\begin{tabular}{|l|l|}
\hline \multirow{2}{*}{ Question } & $\begin{array}{l}\text { Does your company own / have ? } \\
\text { a training center; a training team } \\
\text { A- YES 1- YES } \\
\text { B- NO2- NO }\end{array}$ \\
\hline RESULTS & $\begin{array}{l}\square \quad \text { Only 20\% of organizations responded that they had no training center. Among the } 80 \% \text { of organizations that } \\
\text { do have a training center, 87.5\% of them are clients of TEC in ICT. } \\
\text { About availability of a training team, only 10\% of the surveyed organizations do not have a team dedicated to } \\
\text { training. }\end{array}$ \\
$\begin{array}{l}\text { ANDSONS } \\
\text { COMMENTS }\end{array}$ & $\begin{array}{l}\text { The noted trend is that organizations rearrange themselves to have a training team and center. } \\
\text { This trend is explained by the introduction of modern organization which includes the need to accompany changes } \\
\text { in capital and human skills human inside the company. The effectiveness of such structures in organizations is still } \\
\text { another question. }\end{array}$ \\
\hline
\end{tabular}

Table06 . Question N 06

\begin{tabular}{|l|l|}
\hline \multirow{2}{*}{ Question } & $\begin{array}{l}\text { Training in ICT for the staff of your company is : } \\
\text { A-Mandatory } \\
\text { B-Indispensable } \\
\text { C-Strategic }\end{array}$ \\
\hline RESULTS & $\begin{array}{l}55.56 \% \text { of respondents opted for the 'Strategic' character of ICT training, 33.33\% for 'Indispensable', while } \\
11.11 \% \text { went for 'Mandatory'. }\end{array}$ \\
\hline $\begin{array}{l}\text { LESSONS } \\
\text { AND } \\
\text { COMMENTS }\end{array}$ & $\begin{array}{l}\text { In addition to the indispensable aspect, the strategic aspect of the TEC in ICT is thus demonstrated. This can be } \\
\text { explained by the close relationship between the importance of ICT and of TEC in ICT. }\end{array}$ \\
\hline
\end{tabular}

Table07 . Question N 07

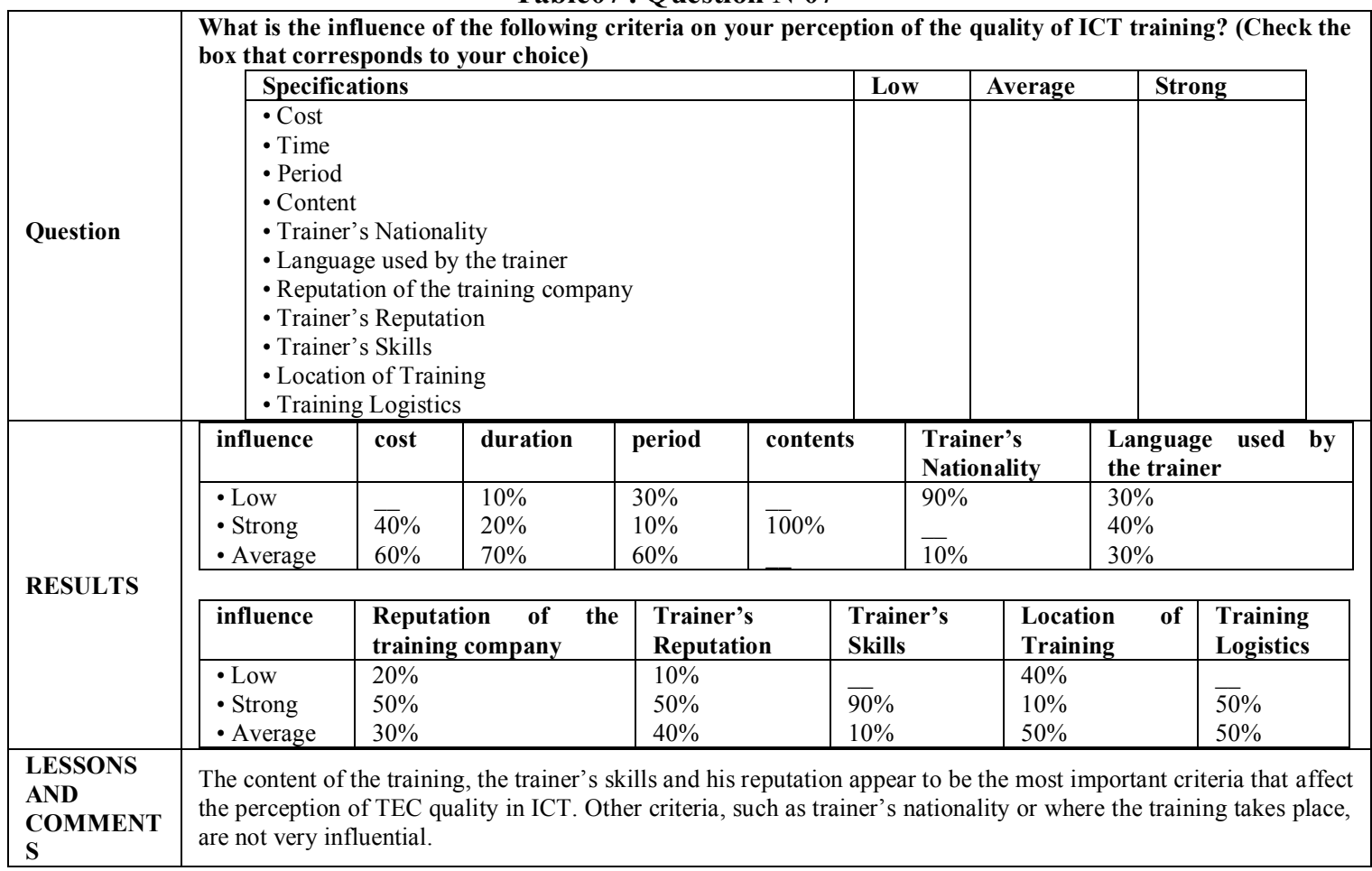

Table08. Question N 08

\begin{tabular}{|c|c|}
\hline Question & $\begin{array}{l}\text { What was the nationality of the trainer and the language used in your last ICT training session? } \\
\text { Nationality: ..................., Language used: ..................... }\end{array}$ \\
\hline RESULTS & $\begin{array}{l}\text { Most trainers ensuring TEC in ICT are Moroccans }(60 \%) \text {, the rest is shared between nationalities especially } \\
\text { French, English, Italian and Egyptian. However, French is the predominant training language ( } 70 \%) \text { against } 30 \% \\
\text { for English. }\end{array}$ \\
\hline $\begin{array}{l}\text { LESSONS } \\
\text { AND } \\
\text { COMMENTS }\end{array}$ & $\begin{array}{l}\text { It appears that French continue to prevail as the official language in trainings, which is logical given the } \\
\text { predominance of the Molière's language in public and private Moroccan institutions, and also taking especially } \\
\text { into account the technological character, which only French and English are able to describe. } \\
\square \quad \text { However, Moroccan skills are predominant and only some trainings on state of the art or new themes, are } \\
\text { provided by foreign skills. }\end{array}$ \\
\hline
\end{tabular}


Table09. Question N 09

\begin{tabular}{|c|c|}
\hline Question & $\begin{array}{l}\text { Do you think there is enough competent local resources to ensureTEC in ICT in Morocco? } \\
\text { A-YES. In this case, are these resources wisely used? } \\
\text { A-1 - Yes } \\
\text { A-2- No } \\
\text { A-3- Other (specify): ....................................... }\end{array}$ \\
\hline RESULTS & $\begin{array}{l}\square 70 \% \text { think that there are enough competent local resources to ensure TEC in ICT in Morocco, while } 30 \% \text { say } \\
\text { the opposite. } \\
\square \text { Of the } 70 \% \text { who favor the first view, only } 20 \% \text { believe these local human skills are not sufficiently exploited } \\
\text { in the global development objective of TEC in ICT in Morocco }\end{array}$ \\
\hline $\begin{array}{l}\text { LESSONS } \\
\text { AND } \\
\text { COMMENTS }\end{array}$ & $\begin{array}{l}\text { The human local skills in the area of ICT exist and exercise in the ICT sector but not necessarily in the } \\
\text { training sector. Each in its own domain, these skills have the technological experiences and are unfortunately not } \\
\text { yet exploited in the activity of TEC in ICT }\end{array}$ \\
\hline
\end{tabular}

Table10 . Question N 10

\begin{tabular}{|c|c|c|c|c|}
\hline \multirow[t]{5}{*}{ Question } & \multicolumn{4}{|c|}{ Submit three themes that you qualify as advanced in IT, Networking and Telecoms: } \\
\hline & & Computing & Networks & Telecom \\
\hline & 1 & & & \\
\hline & 2 & & & \\
\hline & 3 & & & \\
\hline RESULTS & \multicolumn{4}{|c|}{$\begin{array}{l}\square \text { In Computing, SOA, Web } 2.0 \text { and J2EE are in first place for advanced training } \\
\square \text { In Networks, TCP / IP, network security and training on equipment manufacturers (Cisco, Juniper) are proposed } \\
\text { as advanced training } \\
\square \quad \text { In Telecom, Voice over IP, UMTS and NGN are considered state-of-the-art and advanced training }\end{array}$} \\
\hline $\begin{array}{l}\text { LESSONS AND } \\
\text { COMMENTS }\end{array}$ & \multicolumn{4}{|c|}{$\begin{array}{l}\text { The choice of topics emphasizes the fact that some Moroccan companies are up-to-date with technologica } \\
\text { developments. For some, this is because their own production activities are part of the ICT domain. For others, this } \\
\text { is explained by the position of ICT as an essential tool in its everyday activity. }\end{array}$} \\
\hline
\end{tabular}

Table11 . Question N 11

\begin{tabular}{|c|c|}
\hline Question & $\begin{array}{l}\text { What are the ICT training themes to follow incessantly and necessarily by your employees? } \\
\end{array}$ \\
\hline RESULTS & $\begin{array}{l}\text { The proposals made in here, tend to emphasize the Networks theme }(45 \%) \text { which itself is undeniably linked to } \\
\text { Computing }(35 \%) \text { and Telecom }(20 \%)\end{array}$ \\
\hline $\begin{array}{l}\text { LESSONS AND } \\
\text { COMMENTS }\end{array}$ & $\begin{array}{l}\square \text { The needs expressed in terms of training, balance out roughly around } 3 \text { ICT issues, namely IT, Networks and } \\
\text { Telecommunications. } \\
\text { This demonstrates the important nature of these three components as well as the close relationship between them. }\end{array}$ \\
\hline
\end{tabular}

Table12 . Question N 12

\begin{tabular}{|l|l|}
\hline Question & $\begin{array}{l}\text { Are you planning immediate recruitment of ICT skills? } \\
\text { A-YES } \\
\text { B- NO }\end{array}$ \\
\hline RESULTS & $70 \%$ say they intend to recruit ICT skills when 30\% believe that the immediate need doesn't exist. \\
\hline $\begin{array}{l}\text { LESSONS AND } \\
\text { COMMENTS }\end{array}$ & $\begin{array}{l}\square \text { The 30\% who do not intend to recruit ICT skills immediately are all client organizations of TEC in ICT. This } \\
\text { brings us back to the question asked to each organization whose production's activity doesn't revolve around ICT } \\
\text { but around the need for a permanent presence of ICT skills within the organization. That being said, the use of } \\
\text { information technology is increasing in all activities. }\end{array}$ \\
\hline
\end{tabular}

Table13 . Question N 13

\begin{tabular}{|l|l|}
\hline Question & $\begin{array}{l}\text { Has Training in ICT helped you be more productive? } \\
\text { A-YES } \\
\text { B- NO }\end{array}$ \\
\hline RESULTS & $80 \%$ think so \\
\hline $\begin{array}{l}\text { LESSONS AND } \\
\text { COMMENTS }\end{array}$ & $\begin{array}{l}\text { This reinforces the opinion saying that the TEC in ICT enables companies to achieve productivity gains and that the } \\
\text { training investment is not without return. }\end{array}$ \\
\hline
\end{tabular}

\section{The Interview:}

According to the interviews conducted, we deduce the following:

1. The interviewed actors are all aware of the importance of training in general for the development of their organization and its sustainability.

2. They totally share the opinion on the key role now occupied by TEC in ICT and its obvious role in improving productivity.

3. A view was expressed about the importance of the availability of Telecom infrastructure and services at the best prices and the fact that TEC in ICT and ICT's development can stimulate each other.

4. Interviewees believe that the government will towards ICT becomes increasingly clear in order to have a lever for sustainable development. 
5. An important criterion for the positive development of the activity of TEC in ICT would be the report quality / cost of training.

6. A majority of respondents insisted on strengthening the role of the government as a model user of ICT for its own operations and procurement practices and in social areas. This joins the projects e-government and ecommerce struggling to find the necessary momentum to their development.

7. Moreover, the establishment of a governance of ICT development at the national level would also be appropriate.

8. Interviewees support the idea that the current environment is conducive to the creation of consulting firms and ICT training, provided that the companies meet a required level of professionalism and customization of configurations depending on the needs and profiles of their clients.

9. They also agree that the Moroccan human skills are able to fully invest in the TEC sector in general and in the TEC in ICT in particular.

10. The interviewees complained in some cases the lack of interest by Moroccan companies and organizations in the investment in the human capital. However, they all tend to think that things are beginning to change and companies, public or private, are aware today, albeit to variable degrees, of the important role of training in general on their performance. Therefore, some organizations timidly begin to establish an internal policy for the training in employment courses.

11. Among the obstacles that identify interviewees include the phobia of an economic recession in relation to the international situation, and the lack of a clear legal framework and enacted, involving the fact that significant opportunities forOffshoring are missed each year. These barriers constitute an obstacle to the development and professionalization of the activity of FCE in Morocco.

12. Regarding the communication around the FCE ICT and opportunities for businesses, interviewees think that there is a lack in this direction and that providers must become more involved in this aspect. Moreover, it should be encouraged through incentives, the use of IT by SMEs and continually adapt offers OJT in order to develop its attractiveness and competitiveness ..

13. The interviewees emphasize the important role of innovation and R\&D and encourage their promotion. No less important, they emphasized the project to establish the observatory of TEC in ICT to ensure permanent visibility of the ICT sector in Morocco (Employment, Training Companies, ...).

14. Finally, some interviewees suggest that a lobby grouping TEC providers in ICT be created and exercised at the level of this activity in Morocco.

In conclusion, we can say that the use of data from the questionnaires and interviews and analysis, allowed us to locate globally the environmental of the TEC activity in ICT in Morocco and to understand primarily the issues and trends that this quite dynamic sector of great importance for the country's development knows.

\section{Environment Analysis Of The TEC In ICT In Morocco:}

The environment analysis of the TEC activity in ICT in Morocco goes through the following analysis : assessing the nature of the environment, identification of environmental influences, forces of competition and competitive positioning.

The objective of these analysis is to identify opportunities in which the activity of TEC in ICT could build and threats it should bypass. Identification of opportunities and threats with relation to the strengths and weaknesses of the TEC activity in ICT will effectively contribute to the development of the strategic position of the TEC sector in ICT in Morocco.

\section{Nature of the environment:}

InMorocco, the TEC sector in ICT is an environment that knows quite high dynamics due to the constantly evolving technological environment in the world and the choice made by the kingdom to fit into a policy of opening to Offshoring and it encourages the adoption of ICT, and therefore TEC in ICT at all levels of project management and public and private organizations (institutions, companies).

To cope with the different possible developments in the sector, the activity of TEC in ICT in Morocco should strengthen its adaptability. Different actors have to think about the means and structures required to be in a position to fully benefit from the technological development of ICT whatever the national or international political or economic conditions.

\section{The Influence of the environment:}

The identification of environmental influences activity CTF ICT returns to determine the factors macro-environmental which may affect the development and performance of the business in question. We opted for a sociocultural economic PESTLE analysis of the environmental sector FCE ICT in Morocco in its political components, technological and legal. 


\section{- PESTLE analysis}
a. Political aspect
b. Economics
c. Sociocultural aspects
d. Technological aspect
e. Legal aspect

The PESTEL analysis allows us to determine the relative impact of external influences both historically and predictively. Once the key drivers of change identified, it is necessary to examine their respective impact on the business or organization in question. Among the key factors of evolution, we can mention:

- Globalization and the opening of borders

- The arrival of large foreign companies specialized in training in Morocco

- The quality of foreign companies operating in the ICT and whose tech is very variable (call centers, telecom)

- Government policy that considers ICT as a lever for global development

- Tax incentives and training grants

- The regulation of the sector

- The introduction of a legal obligation

- The creation of a union or professional organization comprising the entities

\section{Competitive Positioning: Porter 5 Forces:}

Looking for opportunities provides a competitive advantage and it is then necessary to identify the environmental factors that influence the ability of an organization or business to obtain an advantage.

To do this, we are interested in the analysis of the competitive environment at the activity of TEC in ICT in Morocco. We have used the approach of the five competitive forces, developed by Michael Porter.

The analysis of five competitive forces is to determine the forces that shape the competitive dynamics in an activity. It identifies what are the foundations of competitive strategy in the sector in question.

\section{a. The competitive intensity :}

Competition in TEC activity in ICT concerns the potential competitors that also provide the same product, namely ICT. In this segment, we find both public and private training in the workplace that target students in technical fields. The OFPPT, through its new institutes of applied technology and ICT Offshoring offers skills' trainings for students in these courses. On the private side, you can also find private institutions that provide various courses, including those in ICT. However, the public targeted by these courses are mostly students in training and education and these courses do not constitute a major threat to the TEC in ICT which aims rather at a population of managers and engineers to be formed on sharp enough topics in ICT.

\section{b. The bargaining power of clients and the providers :}

These two forces can be presented simultaneously, as they are closely linked, as clients and providers are part of the value chain. We must then identify what is the bargaining power of the activity of TEC in ICT compared to its providers and clients. In terms of providers, these are the training providers as firms and consulting firms and training. They are either subsidiaries of foreign companies specialized in the field of consulting and training in ICT or Moroccan companies that bring together diverse experienced backgrounds in ICT professions and private training. The power of providers is important in the activity of TEC in ICT and there is an organization APEBI, which brings together various actors and service providers in the field of ICT. Clients are all parties, public and private organizations, including employees and staff that receive training on topics of ICT in the development of skills and career development. Each client manages its portfolio of training its own way and chooses his own training providers. There is therefore no client grouping TEC in ICT in Morocco. However, the clients remains king and his influence on the field of TEC is also important.

\section{c. The threat of substitute products or services :}

Substitute products are products that could replace the training in employment courses proposed by the ICT training providers. Potential training 'recipients', the clients in this case, could then turn to such products or services and abandon the services offered by providers. Such products can be represented by the concept that is sufficiently developed through the Internet and can be in the form of distance learning or e-learning. An example of this is the opening of an e-learning center in Casablanca by the French National Conservatory of Arts and Crafts French (CNAM). The center offers four training and research centers for initial or continuing training: Economics and Management (E \& G), Industrial Science and Technology (ITS), Science and 
Information Technology (ICST), and Work and Society (T \& S) . Another scenario is the use of bank of digital resources for self-training. In addition, intra-company training is also a substitute, but less competitive, because it depends on the theme of training that the internal training department can not provide. In general, the threat of substitute products is very low.

\section{d. The threat of potential entrants :}

Potential entrants may be represented by universities and large Moroccan schools, as well as subsidiaries of foreign universities that enter the Moroccan market due to juicy enough certified training and excitement regarding foreign highly prized credentials by Moroccans. The threat of potential entrants is elevated due to barriers of entry that are minimal (no financial barriers, no transfer costs). Barriers resources, represented by means of telecommunications, are also minimal and those skills are dependent on the recruitment of ICT skills capable of animating sharp continuous training. These skills are available locally and can be recruited abroad if necessary. The market is open and access is permitted by a legal authorization to practice that is not difficult to obtain.

\section{e. The role of the state :}

The state has a limited role in influencing the sector of TEC in ICT in Morocco, be it by regulating the activity through licensing for training in ICT for different potential clients, or providing training grants through OFPPT and CSF. However, we must not lose sight of the potential long-term role of competitor of TEC in ICT through OFPPT activities that could interfere with those of the private TEC now prevalent in the market.

\section{SWOT Analysis:}

SWOT analysis is used to determine whether an organization or activity has already resources and skills needed to respond to changes in its environment, if it is seeking to acquire or develop new ones, or whether it should rather reorient itself to other areas of development. It helps to verify to what extent the resources and expertise of the organization allow to manage the key success factors of the environment.

The following table summarizes the SWOT data from the classification of strengths, weaknesses, opportunities and threats listed in the previous section.

Table14 .SWOT : TEC activity in ICT in Morocco

\begin{tabular}{|c|c|}
\hline Strengths & Weaknesses \\
\hline $\begin{array}{l}\text { - Increasing need of companies in terms of TEC in ICT } \\
\text { - Large contribution of TEC in ICT to performance } \\
\text { improvement in the company } \\
\text { - Fast technological evolution of ICT } \\
\text { - Good local expertise operating in the TEC in ICT } \\
\text { - Flexibility and simplicity of the infrastructure hosting the } \\
\text { TEC sessions }\end{array}$ & $\begin{array}{l}\text { - Small sized and generalist market } \\
\text { - Lack of legal transparency } \\
\text { - Lack of a TEC observatory in ICT in Morocco } \\
\text { - Unsuitability between beneficiaries' missions and the trainings } \\
\text { - Inadequate communication about activities and TEC offers in ICT } \\
\text { - Low budgets for TEC in ICT in companies } \\
\text { - Low Support for TEC providers from the government }\end{array}$ \\
\hline Opportunities & Threats \\
\hline $\begin{array}{l}\text { - Future regulation of the TEC activity } \\
\text { - Great potential of a still booming sector } \\
\text { - Favorable economic developments in Morocco } \\
\text { - Development of new ICT sectors (Banking, Finance ...) } \\
\text { - Increasing awareness vis-à-vis the importance of human } \\
\text { capital and TEC in ICT } \\
\text { - Encouragement of the ICT sector by the government } \\
\text { - Adoption of strategies e-Morocco and Emergence } \\
\text { - Restructuring of universities and colleges } \\
\text { - Certification of TECs in ICT }\end{array}$ & $\begin{array}{l}\text { - No qualification of some training providers (amateurism) } \\
\text { - Insignificant entry barriers for new providers of TEC in ICT } \\
\text { - No localization of advanced training } \\
\text { - Regulatory Changes / tax against the development of the TEC in } \\
\text { ICT } \\
\text { - Government's non-compliance with specifications adopted by the } \\
\text { ICT strategy (Emergence, e-Morocco ...) } \\
\text { - Volatility of foreign resources } \\
\text { - Immigration of local skills (brain drain) }\end{array}$ \\
\hline
\end{tabular}

\section{Prospective analysis:}

The evolution of the activity of TEC in ICT in Morocco could be approached now by a prospective analysis of the sector in the light of distinctive competencies and key success factors previously studied, in addition to some information on the ICT sector in Morocco which are already known and which provide information on trends and positive outlook of this activity in Morocco (Example: The Government is committed to increase the share of the state budget dedicated to IT from 1 to $2 \%$ ).

Thus, a prospective SWOT matrix could be obtained from the medium-term projection (maximum 5 years) of the SWOT matrix obtained in the last section. It is presented in the following table. 
Table 14 .ProspectiveSWOT of TEC activity in ICT in Morocco

\begin{tabular}{|c|c|}
\hline Strengths & Weaknesses \\
\hline $\begin{array}{l}\text { - Regulation of the TEC activity } \\
\text { - Supported Development of the activities Business Process } \\
\text { (Banking, Finance, Accounting) } \\
\text { - Certification of TEC in ICT } \\
\text { - Support by the government of TEC providers and SMEs / SMIs } \\
\text { - Increasing need for companies in TEC in ICT } \\
\text { - Very large role of TEC in ICT in improving business performance } \\
\text { - Supported Technological development of ICTs } \\
\text { - Strong local expertise operating in the TEC in ICT } \\
\text { - Establishment of an TEC observatory in ICT in Morocco } \\
\text { - Lobbying in favor of TEC activity in ICT in Morocco }\end{array}$ & $\begin{array}{l}\text { - Small number of localized advanced trainings } \\
\text { - Insufficient adaptability of the training to the benificiaries' } \\
\text { missions. } \\
\text { - Communication still insufficient about TEC activities and offers in } \\
\text { ICT } \\
\text { - Inadequate budgets by companies to their TEC in ICT }\end{array}$ \\
\hline Opportunities & Threats \\
\hline $\begin{array}{l}\text { - Sector still growing } \\
\text { - Customization of trainings } \\
\text { - Strategy for encouraging ICT by the government } \\
\text { - Specialization of Morocco as a platform destination for } \\
\text { outsourcing European training } \\
\text { - Return of local skills (Brains return) }\end{array}$ & $\begin{array}{l}\text { - TEC companies' activity in ICT threatened by competition from } \\
\text { universities / colleges } \\
\text { - Self-learning and e-learning } \\
\text { - No qualification of training providers } \\
\text { - Installation of foreign giants specialized in Distance Education } \\
\text { and TEC } \\
\text { - Tax / Regulatory Changes against the development of TEC in ICT } \\
\text { - Volatility of foreign resources } \\
\text { - Decrease of the quality of education and training in Morocco }\end{array}$ \\
\hline
\end{tabular}

In this new proposed SWOT matrix, we can see in the 'Strengths', the 'accompanist' role played by the state vis-à-vis TEC providers. In addition, there is a strengthening of the framework for SME/SMI by the State which encourages them to integrate ICT in their activities and to promote an internal policy geared towards the promotion of human capital and thus encouraging TEC in ICT function.

\section{Strategic axes of improvement:}

\section{a. Strategic axis 1: Promoting TEC in ICT in Morocco :}

This axis corresponds to actions related to the promotion of the activity of TEC in ICT in Morocco. It aims to develop the sector, even make Morocco a destination of Offshore training in employment courses, including ICT.

Promoting TEC in ICT goes through accompaniment of the state and the involvement of all actors. It is hinged on the Marketing, communication, development of knowledge of the ICT market, institutional relations (lobbying) ...

\section{b. Strategic axis 2: Pass from a strategy of "response" to a strategy of "supply"}

This strategic axis corresponds to specific actions for TEC providers in ICT to enhance the activity and sell the information. In other words, it is for providers to customize their products and offer multidisciplinary and specialized training that are aligned with customer needs and profile. It is also to bring together the factors of professionalism and competitiveness needed to be able to receive relocated advanced training in Europe.

\section{c. Strategic axis 3: Create an environment conducive to business development of TEC in ICT in Morocco:}

This strategic axis aims at bringing together main conditions to promote the efforts of TEC in ICT investments, including the establishment of a comprehensive enacted regulatory framework that regulates the sector. This axis also corresponds to actions related to acquiring financing for TEC for businesses, Institutional promotion of the label "e-Morocco", encouragement of foreign investment ...

\section{Summary}

Based on our investigation, we find that ultimately the evolution of TEC activity in ICT is constant. A first baseline scenario, quite optimistic and which promises good prospects for development is the arrival of foreign groups specialized in this sector. This necessarily involves structuring the activity from a legal and organizational stand-point. This scenario will professionalize the TEC offer in ICT in Morocco and will also allow training structures to be induced by the arrival of offshore companies. This will result in lower training costs, pushing these companies to seek local solutions. Innovative niches could be created, such as the introduction of well-targeted short trainings in direct relationship with the mission of the beneficiaries. 
A second scenario, rather median, consists of slow and steady growth of the activity of TEC in ICT in Morocco. The main constraint is represented by the absence or scarcity of human resources, 'sharp' trainers in this case. Working methodologies and activity will be penalized as well as certification programs.

\section{References}

[1] 50 Years of Human Development and Outlook 2025, the fiftieth anniversary of the Kingdom's Independence, Official Report.http://www.ofcertification.fr/qualite

[2] Moore, k. (2009). Effective Instructional Strategies: From Theory to Practice. Sage Publications, USA.

[3] Special Education Training Commission, (1999), National Charter of Education and Training, Morocco.

[4] Theall, M. \& Franklin, J. (2001). Using Technology to Facilitate Evaluation.New Directions for Teaching and Learning, ${ }^{\circ}$ 88. San Francisco :Jossey-Bass.

[5] Global Information Technology Report 2006-2007, World Economic Forum, March 2007

[6] The Arab World Competitiveness Report 2007, World Economic Forum (DAVOS)

[7] A. Hax, N. Majluf, The use of the industry attractiveness-business strength matrix in strategic planning, in the coordinated book by R. Dyson, Strategic Planning: Models and analytical techniques, Wiley, 1990 